\title{
THE ACCESSIBILITY OF THE TEST OF ACADEMIC LITERACY FOR POSTGRADUATE STUDENTS (TALPS): STUDENT PERCEPTIONS
}

\author{
Avasha Rambiritch \\ University of Pretoria
}

This paper focuses on the results of a questionnaire administered to students who wrote the Test of Academic Literacy for Postgraduate Students (TALPS) between 2008 and 2010. The purpose of the questionnaire was to elicit information and reactions from test takers about the test. The paper begins by contextualising the problem of student success in higher education, outlining, as well, how a test such as TALPS can contribute positively to student success, before focusing specifically on the voices of the test takers in order to determine how accessible TALPS is to them. This contribution from the test takers is an important one, especially because responsible test developers cannot work in isolation, removed from those affected by the use of test scores. Applied linguists should strive to ensure that the tests they design and use are fair, socially acceptable, and have positive effects. This paper will illustrate that these concerns become important when one works within a framework that challenges test developers to consider questions related to every aspect of the test. In employing a framework that incorporates a concern for the empirical analyses of a test, as well as a concern for the social dimensions of language testing, one is compelled to give a voice to those often ignored, but most affected by the use of the test scores: the test takers. The data gathered will give test developers valuable insight into the feelings and opinions of testtakers.

Key words: applied linguistics, language testing, academic literacy, constitutive, regulative, accessibility, responsibility, social dimension, test-taker rights, intervention programme

\section{INTRODUCTION}

In his foreword to the National Plan for Higher Education, Minister Kader Asmal wrote:

The victory over the apartheid state in 1994 set policy makers in all spheres of public life the mammoth task of overhauling the social, political, economic and cultural institutions of South Africa to bring them in line with the imperatives of a new democratic order. (Ministry of Education, 2001)

Of paramount importance in the new democracy was the transformation of the higher education system, the visions for which were articulated in the Education White Paper 3: A Programme for the Transformation of Higher Education (Department of Education, 1997), its main aim being 'the establishment of a single, national co-ordinated system, which would 
meet the learning needs of our citizens and the reconstruction and development needs of our society and economy' (Department of Education, 1997). This 'new democratic order' meant that, since 1994, tertiary institutions have had to deal with the issue of accepting students whose language proficiency may be at levels that would place them at risk, leading to low pass rates and poor performance. This is a problem not specific to students from previously disadvantaged backgrounds only. Language proficiency is low even among students whose first language is English and Afrikaans, which are still the main languages of teaching and learning at tertiary level. Low levels of proficiency in English generally means that students are not equipped to deal with the kind of language they encounter at tertiary level. For many students, academic language becomes a third or even fourth language.

Van Dyk (2005: 39) outlines three reasons for the low levels of academic literacy and poor pass rates. He states that the first of these is that the political history of segregation and subsequent unequal distribution of resources in the South African educational system has negatively affected a large group of students referred to as historically disadvantaged. The second reason for low levels of academic literacy may be that the South African educational system has a syllabus-driven (positivistic) approach. The third reason is that an increasing number of university students choose to study in English, which is not always their first language.

The reasons articulated by Van Dyk are confirmed in the discussions of other researchers in the field, like Butler and Van Dyk (2004: 1), Webb (2002: 53), Van Rensburg and Weideman (2002: 157) and Mdepa and Tshiwula (2012). While the first and second reasons discussed by Van Dyk are part of a bigger picture and beyond the control of students, teachers and parents, one is led to question why students would choose to be educated in a language that hinders their academic success. One tends to agree with Webb when he states that 'language is fundamental in academic training, and is either a facilitator to academic development or a barrier' (Webb, 2002: 53). Unfortunately, research seems to indicate that in the majority of countries, language has become a barrier to academic success in higher education. So, while in a country like South Africa efforts have been made to widen access to higher education institutions, access does not guarantee success and 'retention and throughput rates for black and coloured students remain extremely worrying’ (Mdepa \& Tshiwula, 2012: 23).

At the University of Pretoria, as at other universities in the country, poor pass rates and low student success are issues of concern. The university also attracts students from other parts of Africa and the world, lending even more diversity to an already diverse environment. Mdepa and Tshiwula (2012:27) note that more than 9500 students from non-SADC African countries studied in South Africa in 2008. Very often these students do not have English as a first language. To ensure student success, measures had to be put in place to assist such students. Fraser's (2008) view that, 'in order to overcome unjust social conditions, the institutionalised obstacles that are preventing participatory parity would need to be dismantled' is particularly relevant here. In this case, an 'obstacle' to student success and participation could be the issue of under-preparedness in the language of instruction. Not accepting these students because of poor language proficiency would simply have been a repetition of the past. Measures were therefore put in place at the University of Pretoria to assist students, particularly at postgraduate level.

For the last seven years, the Academic Writing for Postgraduate Students course has focused on helping to develop the academic writing needs of postgraduate students. Over this period, 
as supervisors recognise the poor academic literacy levels of their students, there has been an increasing demand for the course. This has been the focus of a study conducted by Butler (2007). The study focused on the design of a course for academic writing at tertiary level. Butler states that the 'immediate context of this study derives from the concern that a number of academic departments from a variety of disciplines at the University of Pretoria have expressed about the academic writing ability (and general language proficiency) of their postgraduate students' (2007: 10). He explains that these students are unfamiliar with academic writing conventions, are often unable to express themselves clearly in English, and have not 'yet fully acquired the academic discourse needed in order to cope independently with the literacy demands of postgraduate study' (2007: 10). Information elicited from a questionnaire administered to students and supervisors and from personal interviews with supervisors as part of Butler's study, confirmed that these students experience serious academic literacy problems, with the result that students do not complete their studies in the required time. What became clear from the data derived from these questionnaires and the information from the interviews was the need for a 'reliable literacy assessment instrument' (Butler, 2007: 181) that would 'provide one with accurate information on students' academic literacy levels' (2007: 181). The need for an academic literacy test for postgraduate students had thus been identified and work on the test began.

\section{ABOUT TALPS}

The Test of Academic Literacy for Postgraduate Students (TALPS) was developed because of the need to test the academic literacy of postgraduate students. In deciding on a construct on which to base the test, the test developers chose to base TALPS on the same construct as the Test of Academic Literacy Levels (TALL) (See Van Dyk \& Weideman, 2004). The TALL has in many ways been the sounding board for TALPS. Moreover, the success of TALL has in part been the justification for TALPS. TALL and TALPS are designed to test the same ability - the academic literacy of students - undergraduate in the case of TALL, and postgraduate in the case of TALPS. With regard to TALPS, it was decided to include a section on argumentative writing; it is essential that students follow specific academic writing conventions at postgraduate level and it is important to test whether students are equipped with this knowledge. In addition to this question, there is a question that tests students' editing skills. TALPS was first piloted in May 2007, with the final draft version of TALPS being piloted in September 2007. Based on evidence collected at the a priori stage of test development, TALPS proved to be a highly valid and reliable test (See Rambiritch, 2013). The story of TALPS, i.e. its design and development, is also the focus of a doctoral study (Rambiritch, 2012). This article, however, looks specifically at the social impact of the test and the need for accessibility and fairness in test design.

\section{ACCESSIBILITY IN LANGUAGE TESTING}

The concept of accessibility has not been the main focus of researchers in the field of language testing. A good starting point, in light of this, would be to look at a general definition of the term. According to the Longman Dictionary of Contemporary English (2004), access is defined as having to do with rights of entry and use. In one of the very few definitions of accessibility provided by language testers, Beddow, Kettler and Elliot (2008: 2) define accessibility in general as 'the extent to which an environment, system, or product 
eliminates barriers and permits equal access to all components and services for all individuals'. They define test accessibility as

...the extent to which a test and its constituent item set permits the test-taker to demonstrate knowledge of the target construct. Thus, an accessible test eliminates barriers; permits equal access to all components and features for all test-takers; and yields scores from which subsequent inferences do not reflect error that is the result of incomplete test-taker access (Beddow, Kettler \& Elliot, 2008: 2).

The definitions above indicate that accessibility is concerned with:

1. rights (in this case the rights of the test taker) of entry and use, and

2. ensuring that the test is approachable to test takers and others affected by the use of the test scores.

Likewise, definitions of fairness indicate a concern with equity and a spirit of justice (Stobart, 2007: 276). Kunnan (2004:34) too, in his Test Fairness Framework, focused on two basic principles:

Principle 1: $\quad$ The principle of justice: A test ought to be fair to all test takers; that is, there is a presumption of treating every person with equal respect.

Principle 2: $\quad$ The principle of beneficence: A test ought to bring about good in society; that is, it should not be harmful or detrimental to society.

As applied linguists, these are the very issues that we should be concerned with; i.e. that we design and use tests that are fair and socially acceptable. Weideman (2009) proposes a responsible agenda for applied linguistics, arguing that applied linguistic work should be backed by some foundational framework to ensure that the notions of responsibility, integrity, accessibility and fairness can be articulated in a theoretically coherent and systematic way.

The framework he refers to is based on a 'representation of the relationship among a select number of fundamental concepts in language testing' (Weideman, 2009: 241). The two main functions are the technical mode and the analytical dimension. These do not function in isolation. The relation between the two is 'reciprocal' (Weideman, 2009: 244). The technical mode interacts not only with the analytical mode, however, but is also connected with all other modes. Weideman points out that the technical unity of multiple sources of evidence, the reliability of a test, its validity and its rational justification are foundational or constitutive applied linguistic concepts (2009: 247). These may also be designated necessary requirements for tests (Weideman, 2009: 247). It is important to note that "each of these "necessary" or foundational concepts yields a (technically stamped) criterion or condition for the responsible use or implementation of the technical instrument' (Weideman, 2009: 247). This, according to Weideman, is why we say that tests should be reliable, valid and built on a theoretical base that is defensible in terms of a unity within a multiplicity of sources of evidence (Weideman, 2009: 247).

This technical dimension of the applied linguistic design also links with the lingual, social, economic, aesthetic, juridical and ethical aspects. According to Weideman, the links between 
the technical, qualifying function of the test design and other aspects yield the ideas of technical articulation; test implementation or use; technical utility; the alignment the test has with learning and teaching language; its public defensibility or accountability; and its fairness or care for those taking the test (Weideman, 2009: 247). In employing a framework that incorporates a concern for the empirical analyses of a test, as well as a concern for the social dimension of language testing, one is forced to consider important questions related to every aspect of the test: the validity and reliability of the test; the reason for giving the test; the effect of the test on the test taker; concerns about the design of fair tests; the rights and responsibilities of the test designer; and the rights and responsibilities of the test taker. Clearly, in employing such a framework, one is compelled to give a voice to those most affected by the use of the test scores: the test takers. This article, therefore, focuses specifically on the voices of the test takers with a view to determining how approachable or accessible TALPS is to test takers.

Issues of accessibility and fairness are important considerations in test design, especially in light of the fact that tests have, in general, almost always been seen in a negative light (Shohamy, 1997; 2001; 2004; 2008; McNamara \& Roever, 2006; Stobart, 2007). However, tests, when designed and used correctly, 'have the power to grant access to opportunities and goods that were previously unavailable to the ordinary people' (Fulcher \& Davidson, 2008: 412). This is particularly true for South Africa, with our history of apartheid and segregation. The majority of students who write TALPS come from previously disadvantaged backgrounds, have received an inferior quality school education or have been educated by teachers who have received an inferior quality education. Many of our students coming from rural areas have not studied in English. TALPS is the kind of test Fulcher and Davidson (2008) refer to above - designed with the objective of helping students achieve their goals and dreams. Students' low proficiency levels will no doubt hamper their success at university level. TALPS is used to identify a serious language problem and an intervention is available to help develop the language that these students lack. Used correctly, tests can have positive effects.

This article focuses specifically the accessibility of TALPS, taking a detailed look at the data gathered from a questionnaire (Appendix A) administered to postgraduate students who took the test. This personal contribution of the testees is important to this study, since part of the social impact of a test cannot be determined without it. Ethical clearance for the study was obtained from the Research Proposal and Ethics Committee of the Faculty of Humanities at the University of Pretoria. Before filling out the questionnaire, students were provided with a letter of informed consent which outlined the need for the study, as well as their right not to participate or to withdraw at any point. Students were also informed that the statistical analyses would be done on the group as a whole and not on individual respondents; on completion of this study the data gathered would be incorporated into the database of the Unit for Academic Literacy (UAL) which consists of ongoing research on academic literacy and language-related matters; and that the data gathered would be stored for a period of 10 years, as required by university policy.

\section{THE QUESTIONNAIRE}

A Likert scale (Likert, 1961) was used in this questionnaire to measure student responses. The Likert scale uses either numerical (1-5) or alphabetical (A-E) values. In the case of this questionnaire numerical values were used: 


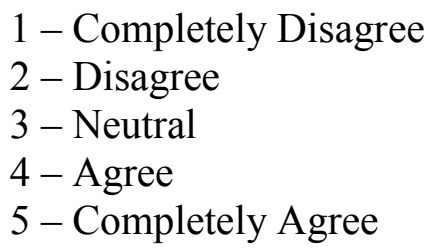

The questionnaire also comprised five open-ended questions which allowed students to voice their opinions and give brief reasons for their choices. The statements in the questionnaire were designed to elicit responses from the testees about different aspects of the test and the testing process: definitions of academic literacy; opinions about the accessibility of the test; the rights of the test takers; preparation for the test on the part of test takers and students' feelings about being considered at risk; and their familiarity with the content of the intervention programme they may have to take if the results of the test show that they may be at risk in terms of their academic literacy levels.

\section{THE PARTICIPANTS}

The questionnaire was administered to students who took the test between 2008 and 2010 . Students were asked to complete the questionnaire after they had completed the test. A total of 150 questionnaires were administered to students applying for admission to Master's degrees in the following fields: Environmental Studies, Taxation, and Agricultural Economics. None of the three groups of students (Environmental Studies, Taxation, and Agricultural Economics) who filled out the questionnaire were writing the test for selection purposes. At the time that the questionnaire was administered, TALPS was a fairly new test and not widely used. This would explain the small number of students who were tested at the University of Pretoria during that period. The researcher received a total of 98 completed questionnaires. Not all questionnaires administered were completed by testees. There could be a number of reasons for this. TALPS is a relatively long test (2 hours). At the end of a test of this nature, some students may have been physically and mentally exhausted. Another reason could be the time factor. Many of these students are working full time and took time off from work to write the test. An extra ten or fifteen minutes to fill out the questionnaire meant more time off work.

In the case of the students applying for admission to the MPhil: Taxation, they were here at the university for a block session of two weeks. During this block session they were expected to attend an orientation for the programme they would be registering for, take TALPS, as well as attend introductory lectures on the courses they would have to enrol for (African Tax Institute, 2010a). Their days were full and busy, with very little free time in between. Many of these students chose not to fill out the questionnaire. All students who were enrolling for the MPhil: Taxation, were expected to take TALPS but were not required to enrol for the compulsory intervention, even if they were shown to be at risk. The reason for this was that these were national and international students who would not be able to attend the lectures. The co-ordinator of the postgraduate programme did indicate that, should the course be available as an online module they would be happy to have their students take it. It must be noted here that testing students who have already been admitted to a programme of study and doing nothing to provide support is a futile exercise, especially if the test results indicate that the student needs support. These students were informed of the need to take the test through information in the brochure handed out to prospective students. 
Students' requiring admission to the MSc: Agricultural Economics had been informed that a prerequisite to admission to the programme was that the students sit for TALPS. Should the results of the test show them to be at risk, they would be required to enrol for the compulsory intervention. Prospective students were informed about the need to take the test at an information session held before the start of the semester. No other information about the test was given to students, with the exception of informing students about the compulsory intervention. The same applied to students enrolling for the M.A and MSc: Environmental Studies degrees. On enrolment, students had to agree to be tested. Should the results of the test show them to be at risk, they were required to enrol for a special bridging course which included the compulsory intervention.

\section{An analysis and interpretation of the results of the questionnaire}

The data collected from the questionnaire were analysed using the Statistical Package for the Social Sciences (SPSS) (Version 17.0). The questionnaire, which comprised of twenty-four statements, rendered a reliability of .736. (Cronbach's alpha). According to Santos (1999:1), Cronbach's alpha determines the internal consistency or average correlation of items in a survey instrument to gauge its reliability. He points out that a Cronbach's alpha of 0.7 is an acceptable reliability coefficient and that 'lower thresholds are sometimes used' (Santos, 1999: 1). An alpha of .736 is therefore acceptable for a questionnaire as it is not being used to make high stakes decisions about the testees. Rather, the purpose of the questionnaire was to elicit responses from the testees to see how the test developers could improve the accessibility of the test.

The last part of the questionnaire included five open-ended questions. The views and opinions of students drawn from these open-ended questions are integrated into the discussion below. These views and opinions appear in the exact words of the student. Also, while the questionnaire used a 5-point scale, in analysing and interpreting the results of the questionnaire the numerical values 1 and 2 (Completely disagree and Disagree) were combined and 4 and 5 (Agree and Completely agree) were combined. Graphs therefore indicate 3 or 4 columns: Disagree, Neutral and Agree or Disagree, Neutral, Agree and Missing (where students did not answer the question).

\section{The accessibility of the test}

The analysis below focuses specifically on the second part of the questionnaire. While the first part of the questionnaire related to academic literacy and language tests in general, the second part of the questionnaire deals specifically with issues of accessibility as they relate to TALPS.

A first important statement deals with whether students were aware of the purpose of the test. Here $69 \%$ of students indicated that they were aware of the purpose of the test (Figure 1) 


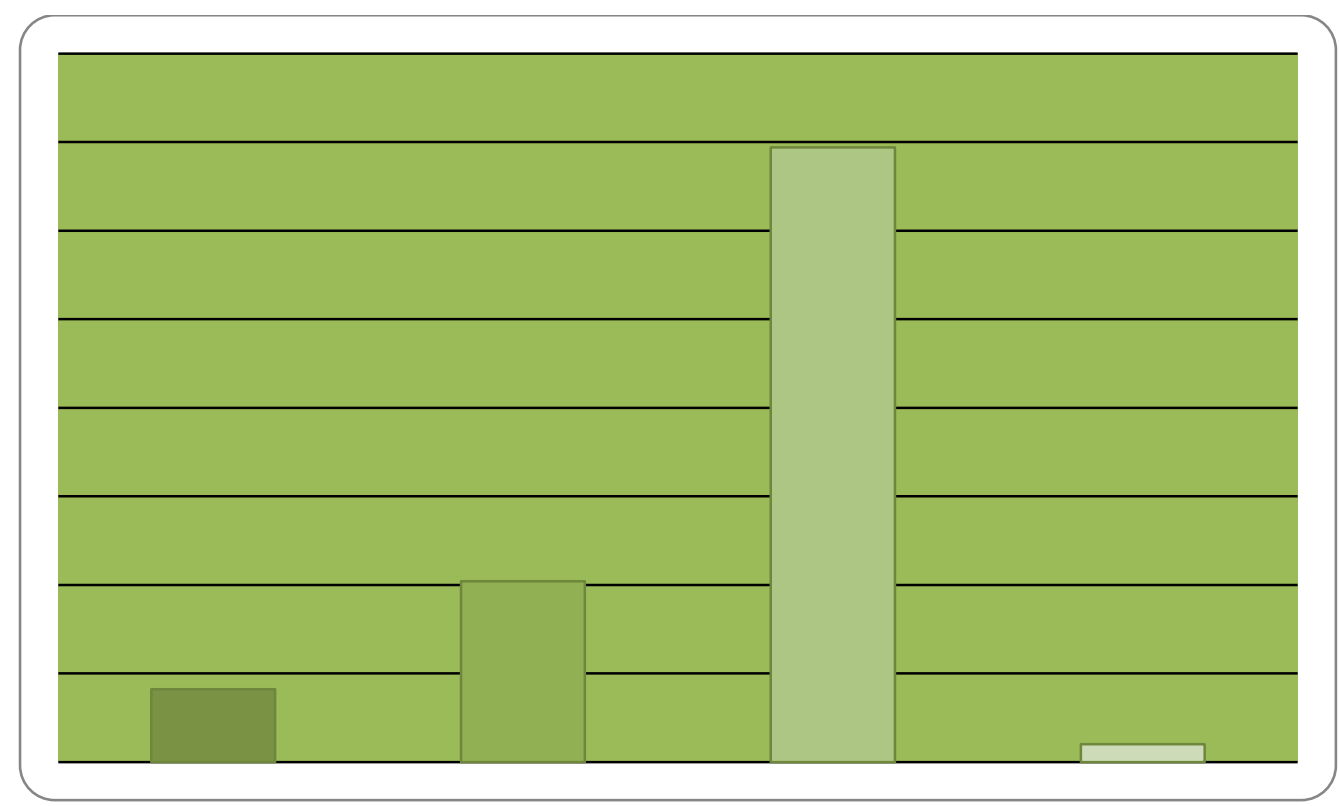

Figure 1: I am well aware of the purpose of the test.

Despite being aware of the purpose of the test, however, 54\% indicated that they were not well prepared for the test (Figure 2). If the majority of students were aware of the purpose for the test, why were they not prepared for the test?

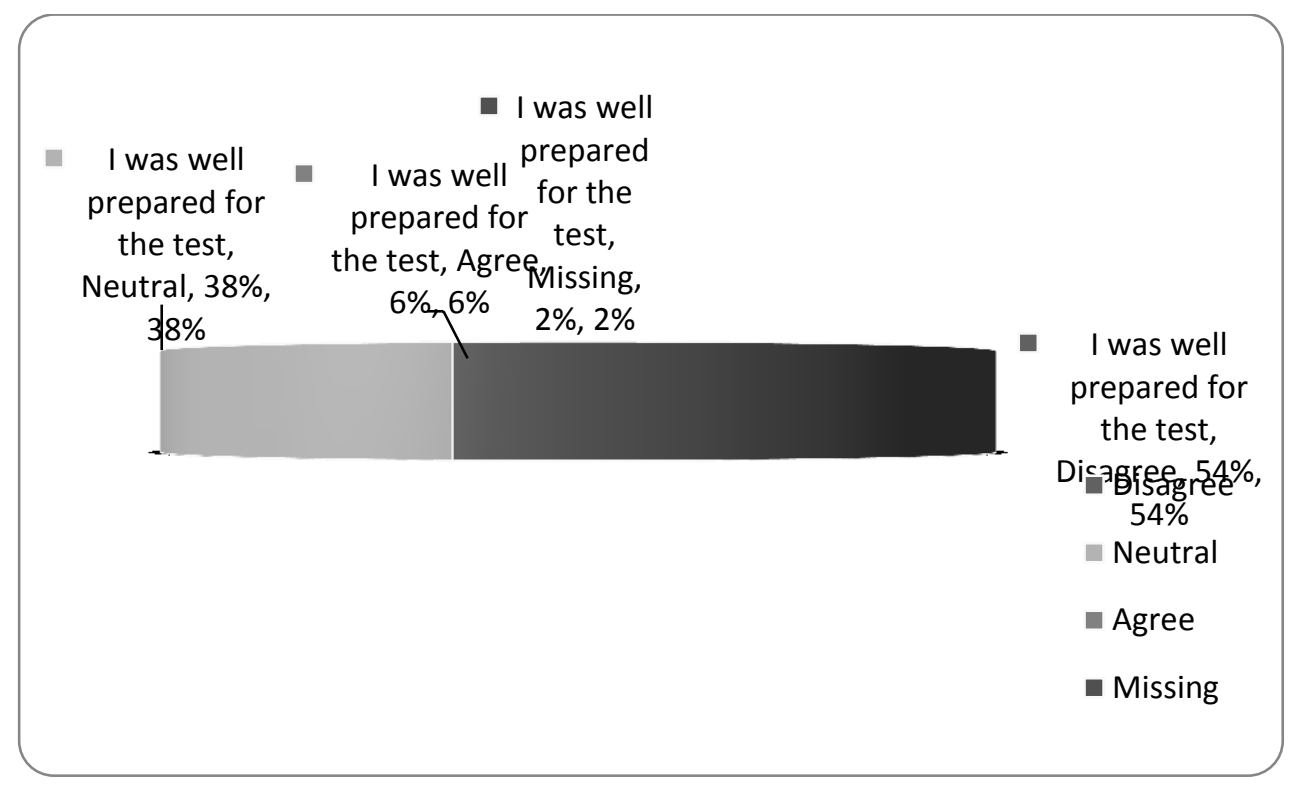

Figure 2: I was well prepared for the test.

Related to this is the indication by $70 \%$ of students that they believe that one needs to prepare specifically for all tests that one has to write (Figure 3). 


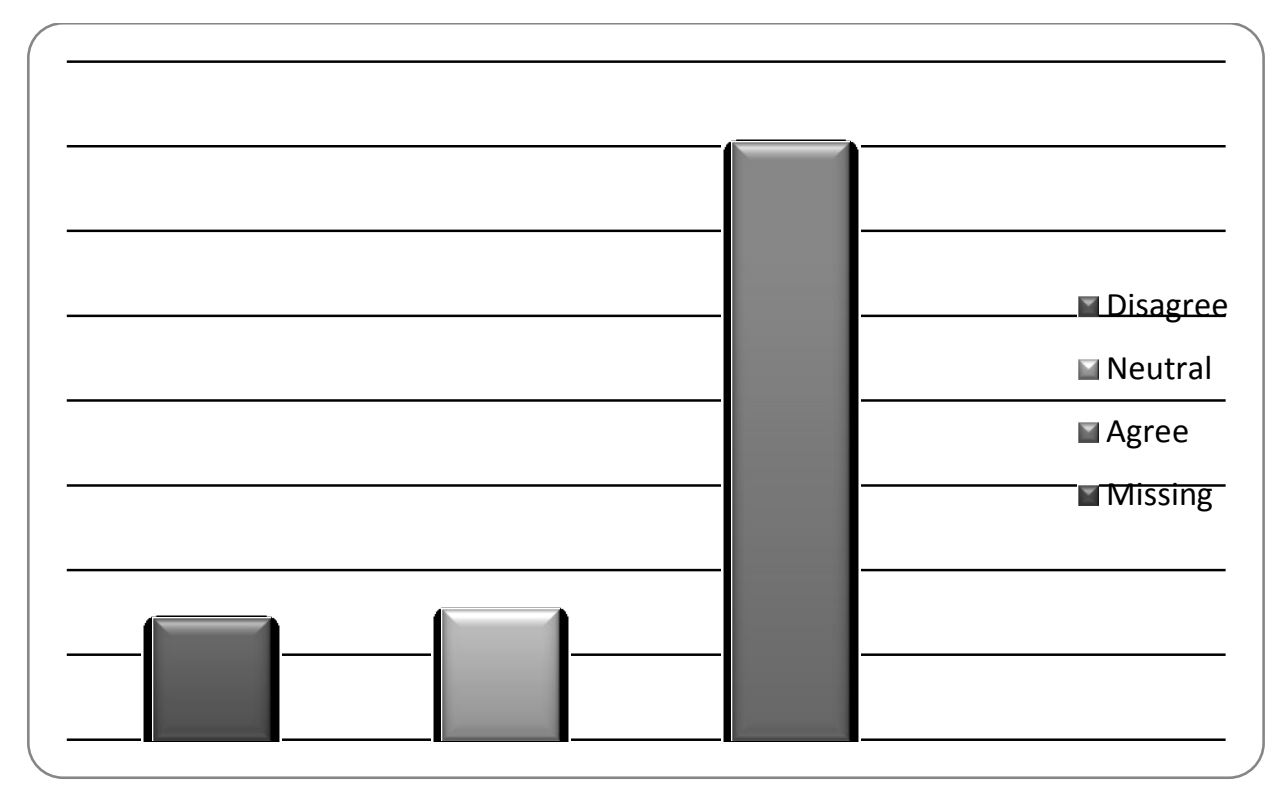

Figure 3: I think that one needs to prepare specifically for all tests one has to write.

So, while the majority of students think that preparation is important, why were more than half of the students not prepared? One of the reasons for this could be that, despite students believing that preparation is necessary, there is also the belief that one cannot 'study' for tests of this nature. What is important here is the difference between the use of the word 'prepare' as opposed to 'study'. Yes, one cannot study for an academic literacy test, but one can prepare for the test by being aware of what the test is about and what it 'looks' like in terms of its format and structure. One can also prepare by ensuring that one is well rested before taking the test. This kind of preparation is essential for any test one writes. Often the most daunting part of taking a test is the fact that one has no idea about what to expect. When students were asked, "How do you think you could have best prepared for the test?" students did indicate the need to have an idea of what to expect in the test as a means of preparation. The plan to make available a sample test on the proposed TALPS webpage will go a long way in addressing these concerns. At present, students are referred to a sample of the test on the website of the Inter-Institutional Centre for Language Development and Assessment (ICELDA): http://icelda.sun.ac.za/index.php/sample-tests. 


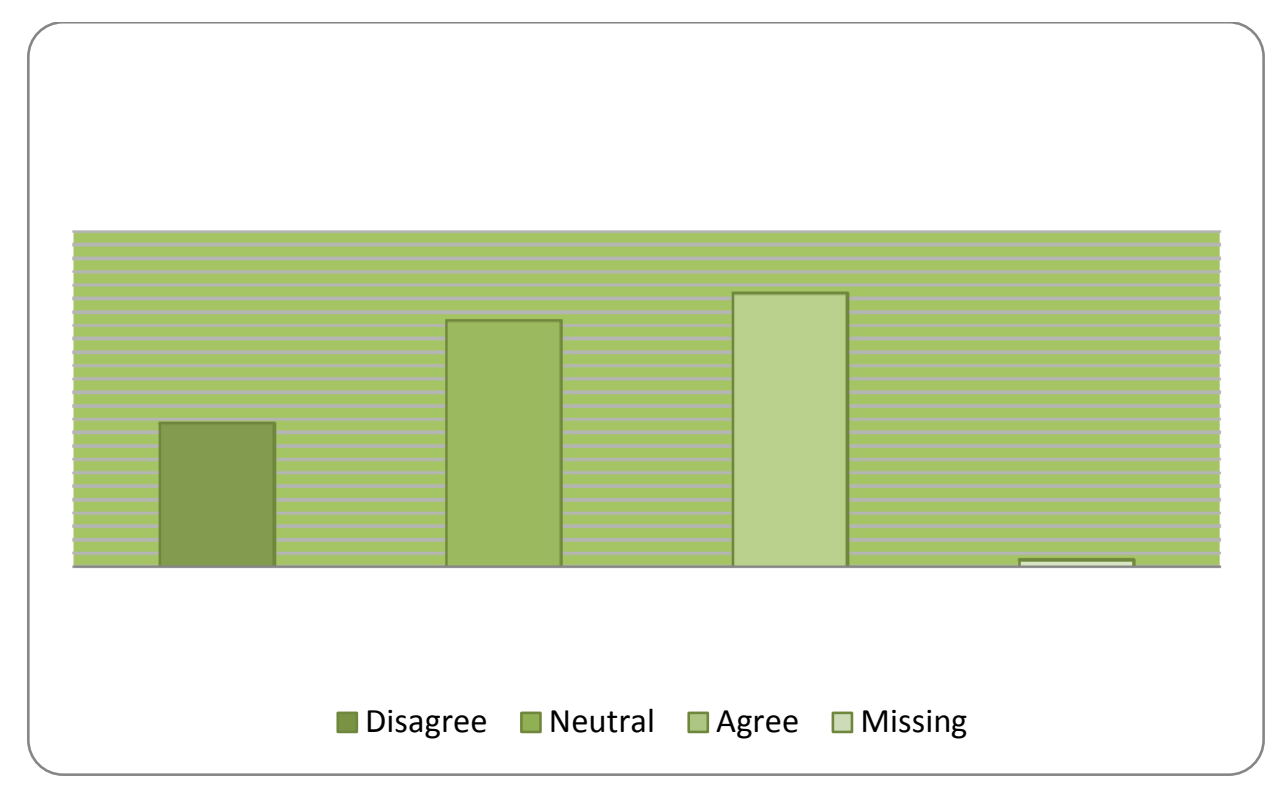

Figure 4: I understand what is meant by the score I receive for the test.

Only $41 \%$ of students indicated that they understood what is meant by the score they would receive for the test (Figure 4). In terms of ensuring accessibility to test takers, this is not a satisfactory percentage. Every student taking the test must understand what is meant by the score. The brochure that will be given to every student making enquiries about postgraduate studies at the University of Pretoria includes a description and explanation of the five codes that the test results are released in. This brochure will be available on the proposed TALPS website and students will be able to download a copy. Information about the interpretation of these codes will be available on the website under "Information for Students". In the case of TALL, chief invigilators are asked to explain this to students before the test. The same is done for TALPS.

Sixty-two percent of students indicated that they understood all the instructions (Figure 5). The instructions in the test are clear and not difficult to understand. Some of these instructions include an example to assist students in understanding better what is required, e.g.:

\section{Section 4}

\section{Text types}

The sentences below are examples of different text types, such as advertisements, instruction manuals, academic textbooks and the like. You must match an item from the first set (26-30) with an item from the second set (A-E). For example, if you think that the language of 26 comes from the same text type as $\mathrm{B}$, then mark $26 \mathrm{~B}$ as your answer on the loose sheet.

\section{OR}

\section{Section 6}




\section{Grammar and text relations}

In the first of these three texts that follow, some words have been deleted. The possible places where they may have been deleted are marked with a / sign. Select, from the places marked A/, B/, C/, D/, where you think the word is missing. The first two have been done for you as examples.

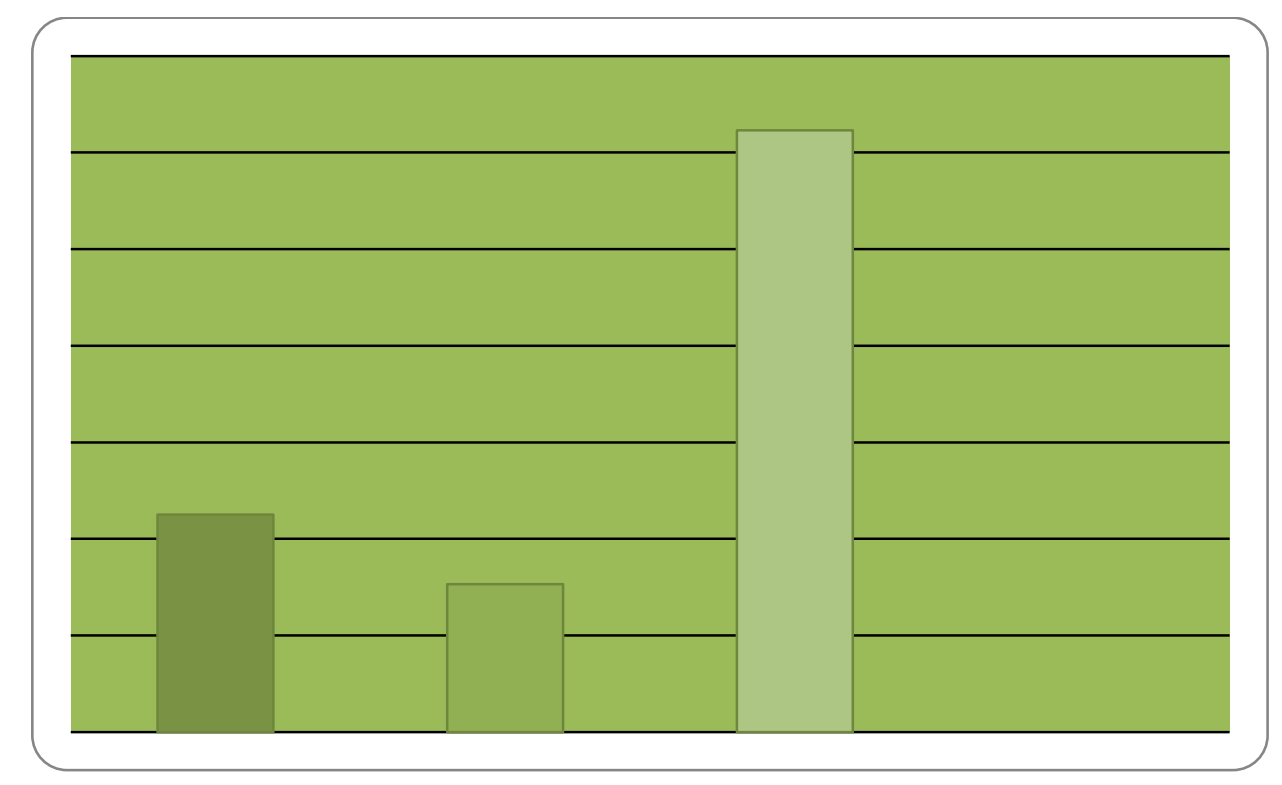

Figure 5: I understood all the instructions.

Interestingly, while $62 \%$ understood the instructions, only $34 \%$ indicated that they understood all the questions. This could be an indication of the problems these students may have with the reading and the understanding of academic texts and/or vocabulary.

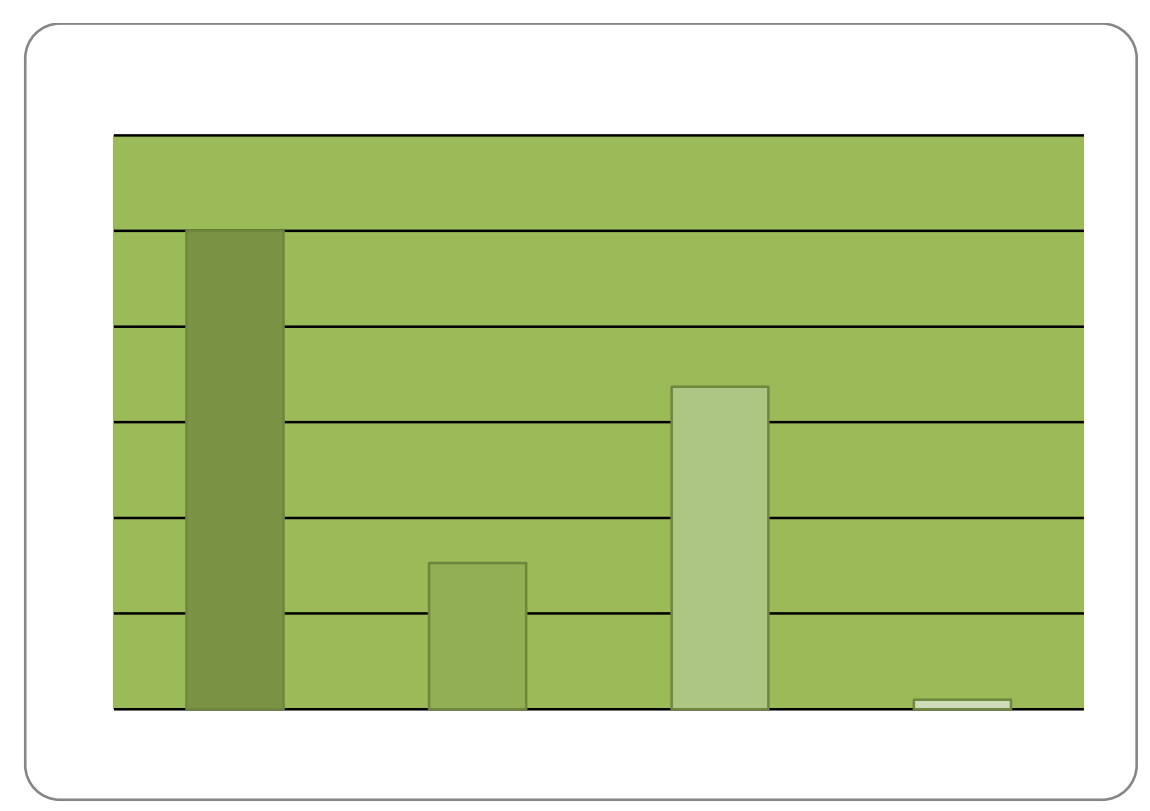

Figure 6: I understood all the questions. 


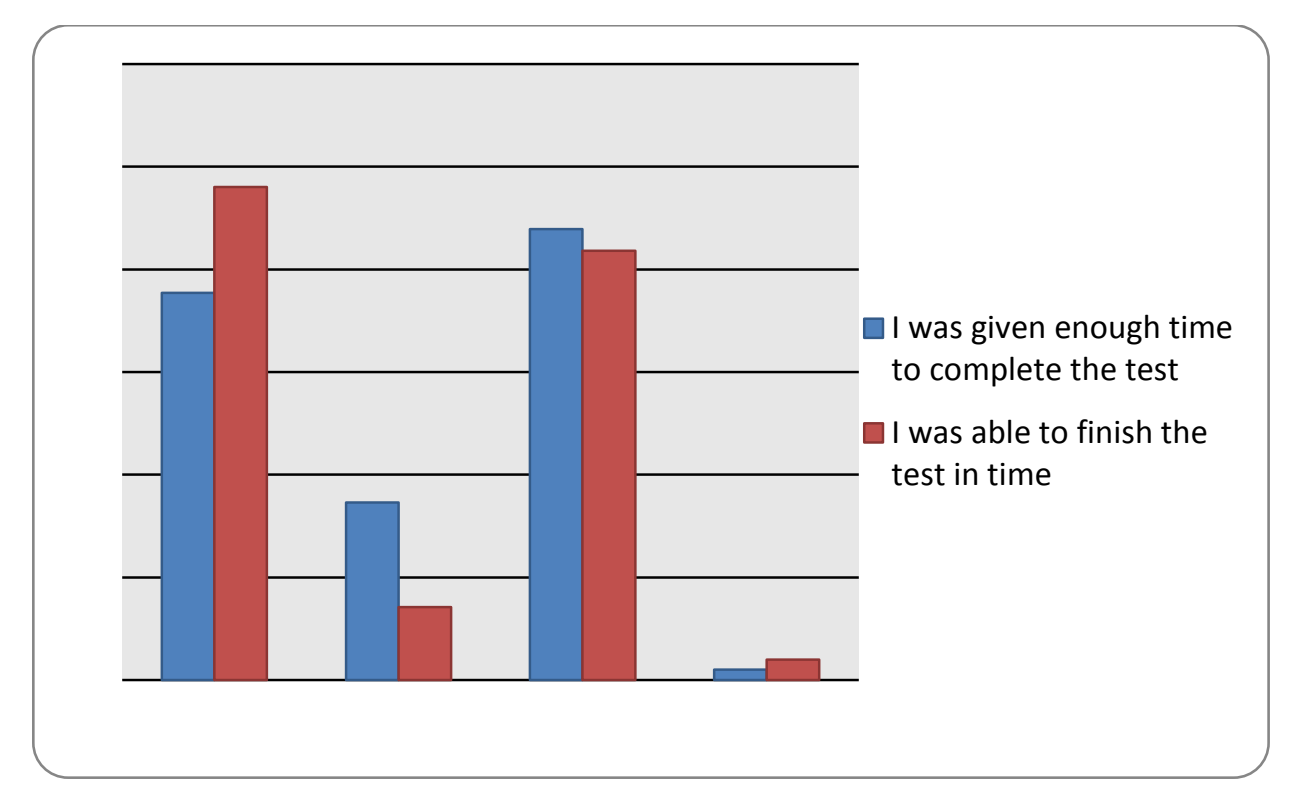

Figure 7: The time given to complete the test

In terms of the time that students are given to complete the test, only $44 \%$ of students agreed that the time was sufficient, while only $42 \%$ of students were able to finish the test in time. The main reason for students not being able to finish the test in time could be the result of students not reading fast enough. It is possible that students are not aware of their reading speed. It is for this reason that there should be a link available on the TALPS website to allow students to test their reading speed. It would also be helpful to provide students with exercises to help them improve their reading speed. Allowing students to complete the sample test online may also give students an indication of how long it will take them to complete the test. It may help dispel the misconception on the part of students that the test is too long or that the time given for them to complete the test was not enough.

One other concern related to the accessibility of the test was the issue of the theme used in the test. One would assume that the vast majority of students would prefer a theme from their own field of study. Instead student responses to this were divided. When presented with the statement ' $I$ do not think that it is important when measuring academic literacy, to work with a theme from my own field', 40\% of students disagreed with the statement, indicating that they would prefer a theme from their field of study; $36.7 \%$ of students remained neutral, while $22 \%$ agreed with the statement (Figure 8 ). 


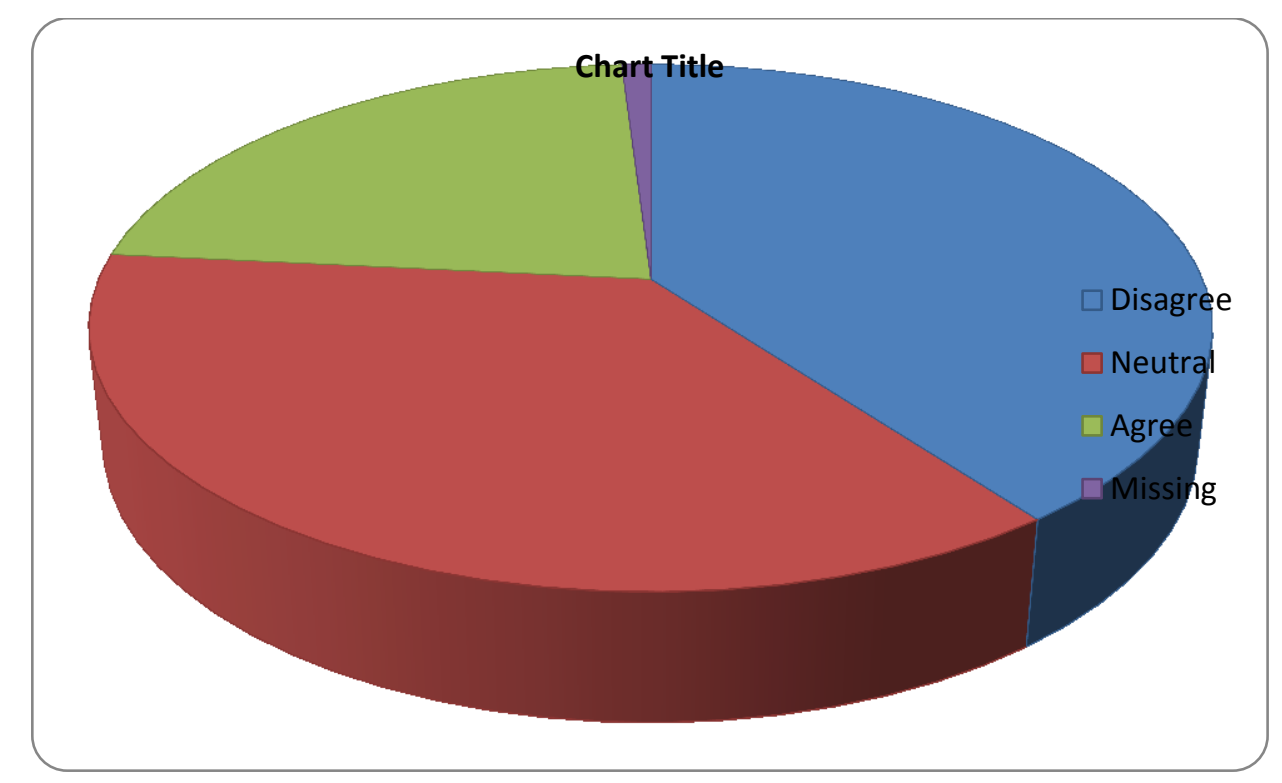

Figure 8: The importance of using a theme for TALPS

When students were asked 'How do you think you could have best prepared for this test?' only $22 \%$ of students indicated that they need to know the topic/theme to adequately prepare for the test.

\section{DISCUSSION}

The analysis above can be summarised into a number of findings:

1. Students, in general, were aware of the purpose of the test but were not adequately prepared for the test. They indicated the need to have an idea of the 'scope' of the test as a means of preparation.

2. While $62 \%$ of the students understood the instructions, half of the students did not understand the questions. Students also indicated that the time given to complete the test was not enough and that they did not finish the test in time.

3. Students' opinion of the importance of using a theme from their field of study was divided - while close to $40 \%$ agreed that a theme from their field of study is important, $37 \%$ remained neutral and only $22 \%$ thought that the theme used is unimportant.

4. Not enough students understood what is meant by the score they will receive for the test.

The data gathered from these students has given test developers valuable insight into the feelings and opinions of test takers. The questionnaire administered to this group of test takers attempted to give a voice to a group often ignored in the entire testing process.

There are four concerns, however for the test developers of TALPS:

1. Students indicated that they were not prepared for the test. 
2. Students felt that the time given to complete the test was not enough, and the majority of students did not finish the test in time.

3. Not enough students understand what is meant by the score they will receive for the test.

One way of addressing these concerns is by making available information to students. Seeing a sample test will provide students with the 'scope' they require. It will also make them aware of how long the test is and how much time they are given to complete the test. They may also have the option of testing their reading speed as well as information on ways to increase it. The brochure and the proposed web page include information about the interpretation of the results of the test. Importantly, this short study has indicated to test developers the importance of including test-taker views in improving the accessibility of a test. While this is by no means the only indication of the strength of a test, it is an important one. Testing experts have, for a long time now, been stressing the importance of a 'holistic' attitude to testing, taking into consideration everyone affected by the use of the test scores - it is the responsibility of individual test developers to put this into practice.

\section{CONCLUSION}

Overall, however, one can deduce that TALPS, to a large extent, is accessible to test takers. The strategies proposed here will ensure further accessibility, especially in terms of making information about the test available to test takers and others interested in the use of the test. It must be noted, however, that, while ways of improving the accessibility of the test have been considered, TALPS is still a fairly new test, having been piloted in 2007. As the test is used, more research will be conducted on the test, and further strategies to improve the accessibility of the test will become apparent.

\section{REFERENCES}

African Tax Institute. 2010a. Information brochure: Master's program in taxation. Pretoria: University of Pretoria.

BEDDOW, PA, RJ KETTLER \& SN ELLIOT. 2008. Test accessibility and modification inventory. Nashville, TN: Vanderbilt University.

BUTLER, HG. 2007. A framework for course design in academic writing for tertiary education. Unpublished doctoral thesis. Pretoria: University of Pretoria.

BUTLER, HG \& TJ VAN DYK. 2004. An academic English language intervention for first-year engineering students. South African Journal of Linguistics, 22(1\&2):1-8.

Department of Education. 1997. Education white paper 3: A programme for the transformation of higher education. Pretoria: Government gazette No. 18207, 15 August 1997.

FRASER, N. 2008. Reframing justice in a globalising world. In Olson, K (Ed), Adding insult to injury: Nancy Fraser debates her critics, pp. 273-291. London: Verso.

FULCHER, G \& F DAVIDSON. 2008. Tests in life and learning: a deathly dialogue. Educational Philosophy and Theory, 40(3):407-417.

KUNNAN, A. 2004. Test fairness. In Milanovic, M \& C Weir (Eds), Studies in language testing 18, pp. 27-45. Cambridge: Cambridge University Press. 
LIKERT, R. 1961. New patterns of management. New York: McGraw-Hill.

Longman Dictionary of contemporary English. 2004. Harlow: Pearson Education.

McNAMARA, T \& C ROEVER. 2006. Language testing: the social dimension. USA: Blackwell.

MDEPA, W \& L TSHIWULA. 2012. Student diversity in South African Higher Education. Widening Participation and Lifelong Learning, 13:19-33.

Ministry of Education. 2001. National plan for higher education. Pretoria: Department of Education.

RAMBIRITCH, A. 2012. Transparency, accessibility and accountability as regulative conditions for a postgraduate test of academic literacy. Unpublished doctoral thesis. Bloemfontein: University of the Free State.

RAMBIRITCH, A. 2013. Validating the Test of Academic Literacy for Postgraduate Students (TALPS). Journal for Language Teaching, 47(1):175-193.

SANTOS, JRA. 1999. Cronbach's alpha: a tool for assessing the reliability of scales. Journal of Extension, 37(2):1-5.

SHOHAMY, E. 1997. Testing methods, testing consequences: are they ethical? Are they fair? Language testing, 14(3):340-349.

SHOHAMY, E. 2001. The power of tests: A critical perspective on the uses of language tests. London: Longman.

SHOHAMY, E. 2004. Assessment in multicultural societies: applying democratic principles and practices to language testing. In Norton, B \& $\mathrm{K}$ Toohey (Eds), Critical pedagogies and language learning, pp. 72-92. New York: Cambridge University Press.

SHOHAMY, E. 2008. Language policy and language assessment: the relationship. Current Issues in Language Planning, 9(3):363-373.

STOBART, G. 2007. Fairness in multicultural assessment systems. Assessment in Education: Principles, Policy \& Practice, 12(3):275-287.

VAN DYK, T \& A Weideman. 2004. Switching constructs: on the selection of an appropriate blueprint for academic literacy assessment. SAALT Journal for language teaching, 38(1):1-13.

VAN DYK, TJ. 2005. Towards providing effective academic literacy intervention. Per Linguam, 21(2):38-51.

VAN RENSBURG, C \& A WEIDEMAN. 2002. Language proficiency: current strategies, future remedies. SAALT Journal for language teaching, 36(1\&2):152-164.

WEBB, VN. 2002. English as a second language in South Africa's tertiary institutions: a case study at the University of Pretoria. World Englishes, 21(1):49-69.

WEIDEMAN, A. 2009. Constitutive and regulative conditions for the assessment of academic literacy. South African Linguistics and Applied Language Studies, 27(3):235-251.

\section{BIOGRAPHICAL NOTE}

Avasha Rambiritch lectures at the Unit for Academic Literacy at the University of Pretoria where her main research interests are academic writing and language testing. E-mail address: avasha.rambiritch@up.ac.za 


\section{APPENDIX A}

\section{UNIVERSITY OF PRETORIA Unit for Academic Literacy Questionnaire for students writing TALPS}

\section{Purpose of the questionnaire}

The purpose of this questionnaire is to determine if this test is a fair and reliable measure of academic literacy. Being academically literate ensures that you are able to "communicate productively and perceptively through the language that you are required to use for academic purposes" (Weideman 2007: x). In order to do this you should be able to do the following:

- Understand a range of academic vocabulary in context;

- Interpret the use of metaphor and idiom in academic usage, and perceive connotation, word play and ambiguity;

- Understand relations between different parts of a text, be aware of the logical development of an academic text, via introductions to conclusions, and know how to use language that serves to make different parts of a text hang together;

- Interpret different kinds of text type (genre), and have a sensitivity for the meaning they convey, as well as the audience they are aimed at;

- Interpret, use and produce information presented in graphic or visual format;

- Distinguish between essential and non-essential information, fact and opinion, propositions and arguments, cause and effect, and classify, categorise and handle data that make comparisons;

- See sequence and order, and do simple numerical estimations and computations that are relevant to academic information, that allow comparisons to be made, and can be applied for the purposes of an argument;

- Know what counts as evidence for an argument, extrapolate from information by making inferences, and apply the information or its implications to other cases than the one at hand;

- Understand the communicative function of various ways of expression in academic language (such as defining, providing examples, arguing); and

- Make meaning (e.g. of an academic text) beyond the level of the sentence.

(Weideman, 2007. Academic Literacy: Prepare to Learn)

\section{Aim of this research}

This questionnaire forms part of a doctoral thesis based on the development of the Test of Academic Literacy for Postgraduate Students (TALPS). The study aims to answer questions about the accessibility, transparency and accountability of the test developers and the test. The aim of the questionnaire therefore is to elicit information, comments, questions and reactions from testees about the test. You cannot in any way be disadvantaged by filling out this questionnaire. You are not required to give us your name or any other personal information. 


\section{How to fill out this questionnaire}

Place a cross in the column containing the number that reflects your opinion most accurately.

\section{QUESTIONS}

\begin{tabular}{|c|c|c|c|c|c|}
\hline & $\begin{array}{c}1 \\
\text { COMPLETELY } \\
\text { DISAGREE }\end{array}$ & $\begin{array}{c}\mathbf{2} \\
\text { DISAGREE }\end{array}$ & $\begin{array}{c}\mathbf{3} \\
\text { NEUTRAL }\end{array}$ & $\begin{array}{c}4 \\
\text { AGREE }\end{array}$ & $\begin{array}{l}\mathbf{5} \\
\text { COMPLETELY } \\
\text { AGREE }\end{array}$ \\
\hline $\begin{array}{l}\text { 1. I think that it is important to know } \\
\text { whether my academic literacy skills } \\
\text { will affect my academic } \\
\text { performance. }\end{array}$ & & & & & \\
\hline $\begin{array}{l}\text { 2. I think that a programme designed } \\
\text { to improve my academic literacy } \\
\text { skills would be useful. }\end{array}$ & & & & & \\
\hline $\begin{array}{l}\text { 3. I think it would be unfair to use the } \\
\text { results of this test to deny students } \\
\text { access into a desired programme. }\end{array}$ & & & & & \\
\hline $\begin{array}{l}\text { 4. I think 'academic literacy' is more } \\
\text { than or different from general } \\
\text { language ability. }\end{array}$ & & & & & \\
\hline $\begin{array}{l}\text { 5. I think that 'academic literacy' is } \\
\text { more or less the same as general } \\
\text { language ability. }\end{array}$ & & & & & \\
\hline $\begin{array}{l}\text { 6. If one is good at languages, one } \\
\text { should have no problems coping } \\
\text { with academic language. }\end{array}$ & & & & & \\
\hline $\begin{array}{l}\text { 7. Being good at languages is no } \\
\text { guarantee of being successful in } \\
\text { using academic language. }\end{array}$ & & & & & \\
\hline 8. I was well prepared for the test. & & & & & \\
\hline $\begin{array}{l}\text { 9. I am aware of the purpose of the } \\
\text { test. }\end{array}$ & & & & & \\
\hline $\begin{array}{l}\text { 10. I understand what is meant by the } \\
\text { score I receive for the test. }\end{array}$ & & & & & \\
\hline
\end{tabular}




\begin{tabular}{|c|c|c|c|c|c|}
\hline & $\begin{array}{c}1 \\
\text { COMPLETELY } \\
\text { DISAGREE }\end{array}$ & $\begin{array}{c}\mathbf{2} \\
\text { DISAGREE }\end{array}$ & $\begin{array}{c}\mathbf{3} \\
\text { NEUTRAL }\end{array}$ & $\begin{array}{c}4 \\
\text { AGREE }\end{array}$ & $\begin{array}{l}\mathbf{5} \\
\text { COMPLETELY } \\
\text { AGREE }\end{array}$ \\
\hline 11. I understood all of the instructions. & & & & & \\
\hline $\begin{array}{l}\text { 12. I was given enough time to } \\
\text { complete the test. }\end{array}$ & & & & & \\
\hline 13. I understood all the questions. & & & & & \\
\hline 14. I was able to finish the test in time. & & & & & \\
\hline 15. I have a positive attitude to tests. & & & & & \\
\hline $\begin{array}{l}\text { 16. I always understand what the results } \\
\text { of a test will mean for me. }\end{array}$ & & & & & \\
\hline 17. Tests are sometimes unfair. & & & & & \\
\hline 18. Test takers have little or no rights. & & & & & \\
\hline $\begin{array}{l}\text { 19. If this test shows me to be at risk I } \\
\text { think that people will see me as a } \\
\text { failure. }\end{array}$ & & & & & \\
\hline $\begin{array}{l}\text { 20. I do not believe that a test is a good } \\
\text { measure of my performance. }\end{array}$ & & & & & \\
\hline $\begin{array}{l}\text { 21. A poor performance on a test can } \\
\text { lead to detrimental consequences. }\end{array}$ & & & & & \\
\hline $\begin{array}{l}\text { 22. I do not think that I can in any way } \\
\text { be disadvantaged by taking this test. }\end{array}$ & & & & & \\
\hline $\begin{array}{l}\text { 23. I think that one needs to prepare } \\
\text { specifically for all tests one has to } \\
\text { write. }\end{array}$ & & & & & \\
\hline $\begin{array}{l}\text { 24. I think that it is not always possible } \\
\text { or desirable to prepare for all tests } \\
\text { beforehand. }\end{array}$ & & & & & \\
\hline $\begin{array}{l}\text { 25. Now that I have written the test, I } \\
\text { think that the best preparation may } \\
\text { have been attention to the way I } \\
\text { have been using language in my } \\
\text { own field all along. }\end{array}$ & & & & & \\
\hline
\end{tabular}




\begin{tabular}{|c|c|c|c|c|c|}
\hline & $\begin{array}{c}1 \\
\text { COMPLETELY } \\
\text { DISAGREE }\end{array}$ & $\begin{array}{c}\mathbf{2} \\
\text { DISAGREE }\end{array}$ & $\begin{array}{c}\mathbf{3} \\
\text { NEUTRAL }\end{array}$ & $\begin{array}{c}4 \\
\text { AGREE }\end{array}$ & $\begin{array}{c}\mathbf{5} \\
\text { COMPLETELY } \\
\text { AGREE } \\
\end{array}$ \\
\hline $\begin{array}{l}\text { 26. I think that if the theme of the test } \\
\text { was related to my field of study, I } \\
\text { would have done much better. }\end{array}$ & & & & & \\
\hline $\begin{array}{l}\text { 27. I would have liked the test to have a } \\
\text { theme from my own field of study. }\end{array}$ & & & & & \\
\hline $\begin{array}{l}\text { 28. I do not think that it is important } \\
\text { when measuring academic literacy, } \\
\text { to work with a theme from my own } \\
\text { field. }\end{array}$ & & & & & \\
\hline $\begin{array}{l}\text { 29. I think that if the test shows me to } \\
\text { have risk associated with language, } \\
\text { I would feel very disappointed. }\end{array}$ & & & & & \\
\hline $\begin{array}{l}\text { 30. If I am shown to be at risk, I would } \\
\text { gladly do a course to improve my } \\
\text { language. I cannot risk extending } \\
\text { my studies. }\end{array}$ & & & & & \\
\hline $\begin{array}{l}\text { 31. I am familiar with the content of the } \\
\text { course I may have to take if the } \\
\text { result of the test shows me to be at } \\
\text { risk. }\end{array}$ & & & & & \\
\hline
\end{tabular}


THE FOLLOWING QUESTIONS ALLOW YOU TO EXPRESS YOUR OPINION AND GIVE BRIEF REASONS

1. What is your understanding of the concept 'Academic literacy'?

2. How do you think you could have best prepared for this test?

3. Do you think a test of this nature is at all necessary? Explain.

4. Would you feel stigmatised in any way if the results of the test show you to be at risk? Explain briefly.

5. If you were shown to be at risk, how will you feel about taking a compulsory academic writing course? 